\author{
Agata Matysiak-Błaszczyk*, Jerzy Modrzewski** \\ * Adam Mickiewicz University in Poznań \\ ORCID: 0000-0002-7420-7288 \\ DOI: https:doi.org/10.35464/1642-672X.PS.2019.3.20 \\ ${ }^{* *}$ Adam Mickiewicz University in Poznań \\ ORCID: 0000-0002-4432-6497 \\ DOI: https:doi.org/10.35464/1642-672X.PS.2019.3.20
}

\title{
The condition and destruction of the socialization function of local rural communities
}

A B S T R A C T: Despite progressing urbanization, Poland essentially is a country village. Poland's ruralness - if it is understood as that part of the country that is outside of cities, occupies more than $90 \%$ of the country's territory. In Poland, within rural areas, we have over 43 thousand so-called basic settlement units. Since 1950, the number of the largest villages (over 1000 inhabitants) and large villages (over 500-1000 inhabitants) located close to the cities has been systematically growing and the dynamics of their number and population growth shapes the phenomenon of gentrification (settling in the countryside of the urban population mainly representing the middle class) in tandem with their depreciation and largely proletarianization. Residents of rural areas make up about $40 \%$ of the Polish population, revealing an upward trend, dealing with their existence in various, not necessarily traditional and effective ways. Thus, the percentage of affluent people and those experiencing social or material mires increases in Polish villages. This material stratification of the population of Polish villages, families inhabiting them, raises new disturbing phenomena and states of affairs, and their growth dynamics are shaped, among others, the above - mentioned by the processes of gentrification, deagrarianization and proletarianization of village communities.

KEYW ORDS: Village, rural environment, rural local community, rural socialization, pedagogy of the rural community, rural family, its functions and dysfunctions.

\section{Introductory notes}

Terms and the concepts derived from them, such as: village, rural area, rural environment, constitute recognized theoretical categories and thus 
research categories, allowing for scientific identification and comprehensive description of the fragments of the natural, ecological and socio-cultural reality that they indicate. Their application in the construction of scientific theory can be observed in various basic disciplines of science, such as: sociology of countryside and agriculture (Turowski 1993; Gorlach 2004; Bukraba-Rylska 2013) ${ }^{1}$, in ecological psychology (Bell i in. 2004; Bańka 2018), anthropology and in particular ethnography, in demography and historical or geographical sciences, but also in many praxeological sciences, especially in agriculture, economics, as well as in pedagogy - especially in social and environmental pedagogy (Sroczyński 2006; 2017; Winiarski 2017). In the scientific disciplines indicated above there are numerous attempts to operationalize these terms, providing them with meanings and uses that are more or less respected in science (Stanny 2014). This paper will pay particular attention to such an understanding of them that identifies the above mentioned complex of geographical, ecological and socio-cultural features that co-create a rural type or kind of system - a settlement system and the community that inhabits it - with various functions characteristic of it (them), and among them - the socialization function, which is performed successfully ${ }^{2}$ or poorly mainly in relation to people living in this environment, but also in relation to other people who remain in permanent or temporary spatial distance from it (this system), but not mentally, and thus who are subject to its socializing influence.

1 Nowadays, the sociology of countryside (and agriculture - rural areas) focuses on the following areas of interest: populations of inhabitants of rural areas, included in social categories together with their civilization transformations, institutional equipment, natural resources (natural rural environment) and agriculture (agricultural practices and technologies, agricultural sciences) (Buttel in: Smelser, Baltes, 2001, pp. 13429-13433; Halamska et al. 2019).

2 The success of the socialization function, and therefore also its destructiveness in relation to, among others, the rural community, is a highly complex qualification that requires the identification of its essential reference points. The effects of the socialization function of a rural community can be and are usually related to the axionormative order determined by tradition, custom, inherited culture, which is - in the Polish countryside and its community - significantly sacralized and often ethnically and regionally oriented. These Polish rural customs are perfectly and comprehensively described by J. Styka (1999). Also (Styka 1995) and a little earlier (Styka 1993 - reprinted in Zych 1998), also in fragments in (Sipińska et al. 2010). They can be and often are relativized to the civilization order prevailing in a given state society as progressive and/or conservative, and finally, regardless of tradition, customs or fashion, they are qualified according to the legal order in force in a given country, but these qualifications and their personal consequences do not necessarily gain acceptance in a rural community respecting local standards of qualification of behaviors as correct or destructive, e.g. determined or relativized to the norm established by a church institution. 


\section{The phenomenon of rural local community as a subject of pedagogical intervention (pedagogization)}

Village, rural environment with the characteristics of a local spatial structure, with its own (typical) features, various genetic, structural and functional significance is also a subject of interest of sociology of education and social pedagogy, where the extensive theoretical and factual knowledge, documented by numerous publications about this kind (type) of local environments and their educational or socialization functions, has been gathered so far (Kawula 1973; Wincławski 1973; Kwaśniewicz 1976; Grabski 1987; Kozakiewicz 1989; Borowicz 2000; Domalewski 2001; Papież 2006; Szafraniec 2006; Domalewski 2019). However, in both those sub-disciplines we are dealing with a situation of frequent and difficult to identify blurring of their specific aspects of approaching this subject, which complicates the qualification of their publications devoted to rural educational environments to one or the other sub-discipline of science. Such qualifications usually take into account the social and cultural characteristics of the rural environment, defined as a local rural community (Park 1936, p. 4; Hawley 1950; Bernard 1962; Kaleta 1991-2013; Kaleta 1996-2001); which displays the characteristics of a functionally integrated entity (entity), which for thousands of years has been autarkic and more or less successfully satisfying the existential needs of the people and family groups who co-create it, significant for the closest and distant surroundings, region, country and the communities inhabiting it, and which in the 20th century has revealed rapidly increasing signs of disintegration or even self-destruction caused by rapidly occurring urbanization processes ${ }^{3}$.

Despite the above-mentioned destructive influence of industrialization processes and urbanization on rural communities (Wesołowska 2018), the notion of local community, applied to a set of people living in a relatively small area, is also applied nowadays in many basic and praxeological scientific disciplines that are interested in, among others, rural environments ${ }^{4}$ and social pedagogy. It most often repeats the understanding of this concept as a set

\footnotetext{
3 The transformation of traditional (including rural) communities into contemporary urban (metropolitan) communities was a fundamental focus of the authors of the sociological concept (theory) of transformation (Janowitz 1961).

4 Jan Turowski, in his work Socjologia (1994) in chapter XI, devoted to local communities, on p. 211, writes that: "There is no more extensive sociological literature than the collected publications on local communities".
} 
or structure co-created by the inhabitants of the territory occupied by them, referred to as the local environment, pursuing a common interest (existential), sharing similar or identical values, entering into relatively stable relations (family, neighborhood, religious, institutional) creating specific bonds, the sharing of which results in local sentiments, maintaining the psychological stability of individuals, constituting a basic source of knowledge about the world and the place of determining meanings present in the local culture (Mendel, Theiss 2019) .

This is how Aleksander Kamiński (1974) interpreted this concept, pointing out that local community consists of a small territorial community, which includes all the people an individual may encounter directly thanks to the proximity of their residence, and a little later we will discuss the transparency or directness of their social participation (Modrzewski, 2007). This concept was also referred to by Kamiński's contemporary sociologists of education while constructing sociological concepts of education, teaching and rural socialization. For example, Stanisław Kowalski defined the local community as "the most important component of the educating society" (underlining added). According to the author, the local community is a space where educational processes take place and it is the most representative social space that includes the educational microenvironments of social participation of various individuals and groups, local communities should have a system of institutionalized education" (Kowalski 1969; 1974; Łoś 1972; Gołębiowski 1977; Wincławski 1973; 1976). The local rural community, understood in this way, played and continues to play a significant role in shaping the image of the socialization processes of the individuals and groups that co-create them (Kowalski 1974, pp. 27-41).

5 Despite such a rapidly growing number of publications devoted to local communities, they do not provide any definite position on the operationalization of this concept, but rather present positions signaling the destruction of their original forms - as social structures with a high level of their internal integration (bonds integrating their members - inhabitants). In his monograph, J. Turowski provides a systematic review of the sociological definitions of the theory of local communities, pointing to the particular merits of their development and structuring: R.E. Park, E.W. Burgess, A.H. Hawley, L.F. Shnore, R.L. Warren, M. Webber, R.M. MacIver, G.A. Hillery, C. Bell, H. Newbi, D.B. Clark, M. Stacey, M.P. Effrat and many others. See also (Starosta 2002, p. 104).

6 This rural specificity of the processes of socialization (upbringing) was signaled by the authors and editors of monographs and collective works devoted to: to rural families, schools, parishes or institutions promoting culture already in the interwar period and later, especially in the second half of the 20th century (Chałasiński 1938; 1969; Kowalski 1969; Kwieciński 1972; Markowska 1976; Damrosz 1979; Milas 1980; Nowak 1988; Kielar, Radochoński 1989; 
This interpretation was also shared by other social pedagogues, e.g. Mikołaj Winiarski (2000) pointed out that the local environment is characterized by: clear territorial boundaries and usually its own material and institutional infrastructure, co-existence of community-type groups (with the domination of personal, friendly, neighborly or family relations) and association groups (goal-oriented organizations). Residents of the local environment are aware of their "settlement" within specific territorial frames, share a sense of unity and act together in case of e.g. threats or difficult random situations. In the local community there is a system of social control, usually without the participation of professional officers, there are clear social powers, direct personal contacts can be observed among children and youth, the network of material and personal relations is not an interference in the sphere of private life, but rather enriches it, and the local environment undergoes rapid changes.

In opposition to a society that is relatively isolated, with considerable dynamism, the so-called open societies appear today, and the sources of this situation are diverse, e.g. loosening of interpersonal ties, increasing anonymity of life, emphasizing individualism, disappearance of the institution of neighborhood, disappearance of the importance of social control, etc. (Pilch 2002, p. 300). However, conditions conducive to decentralization in a way mobilize local environments to fulfill (or fulfill in them) many tasks and objectives, e.g.: creation of local values with simultaneous care for the common good, satisfaction of basic and higher needs of all generations, creation of conditions supporting the development of various types of activity, etc. (Wine 2000, s. 142), which is directly related to the need to activate this environment and utilize its social capital. Tradition plays a significant role here (Kurczewska et al. 1998; Bielska 2001). This is because the transformation processes, despite making them similar in terms of institutional facilities, technical equipment and social infrastructure, did not result in the deprivation of territorial groups of their cultural identity.

Local communities, as part of the global society, make their co-creators and the people appearing in them social persons, at the same time creating a space for their social participation mainly in the life of such small communities. "The community of living conditions therefore creates a community of social experiences that provides knowledge of the rules of the social game. It also functions as spiritual points of reference for the development of one's own

Dudkiewicz 1990; Hryniewicz 1991; Nikitorowicz 1992; Radochoński, Horbowski 1996; Kawula 2002; Gorlach et al. 2003; Marzec-Holka 2015; Bukraba-Rylska 2019, t. 1). 
life path." (Frąckowiak 2005, p. 20). The local environment should be treated as a space of civic education, triggering the activization of individuals and serving the welfare of local and regional communities and the entire society (Radziewicz-Winnicki 2003; Theiss 2018). Wiesław Theiss (1996, pp. 16-23) referred to such local communities using the term: a "small homeland" which is a "structure composed of feelings, intellect and actions closely related to what is close to us - e.g. home, neighborhood, landscape, local culture and tradition $[. .$.$] reality close to symbols and myths, but at the same time deeply$ rooted in material facts". (Ossowski 1984).

Therefore, social pedagogues perceive them as opportunities for their pedagogical optimization, saturating them with values and patterns recognized by them, enhancing the existential condition and multiplying biographical chances of the next generations socializing in such communities, and at the same time they perceive and use the possibility of counteracting, avoiding and correcting the signs of their existential misery, functional clumsiness or socialization dysfunctions appearing in the social practices of such communities, in this case most often qualified from the position of their observers and initiators of pedagogical interference into them, correcting or reconstructing such states of affairs.

Thus, all these numerous pedagogical interferences in the life and functioning of rural local communities, which exist in the found and cocreated by them rural local environment, can be considered as a kind of its pedagogization. The very term "pedagogization" appeared in the social and scientific discourse already in the middle of the 20th century in German pedagogy (Trohler 2013). In the Polish pedagogical literature it was popularized by Z. Kwieciński (2011) in the article: "Pedagogizm - wariacje wokól rozumienia kategorii", although earlier the term "pedagogism" appeared in an article by T. Hejnicka-Bezwińska, "Pedagogizm (kontynuacja-przezwyciężenie)" which does not mean that it has not been used in scientific and non-scientific discourse before (Czyżewski et al. 2013). In the sense used in the text, we give it a broader meaning. Referring rather to the notion of "pedagogization of social problems" used in Western pedagogy. (Lambeir, Ramaekers 2008). In this context, understood as interference in the life of the rural community in order to support it in its successive resolution of: existential problems (successful continuation), and development problems (preservation of conviction and making efforts to ensure a successful perspective) and thus as interference made with the intention of obtaining (and often regaining) and multiplying of existential, developmental and prospective well-being, understood in one way or another, which was often pointed out in the works of the dignified 
jubilarian, author and editor of the editorial project designed by him and wonderfully implemented under his scientific patronage (Pilch 2003-2010).

\section{Contemporary rural local communities}

A still present dilemma in defining a village is to determine what is no longer a city, but a village, and what are its characteristics (Stanny 2014). For example, Jan Papież points to four criteria according to which it is possible to identify rural environments in individual countries. These are: demographic, administrative, employment and multifactorial criteria (Papież 2007, p. 425). In the sociology of countryside a village is defined as a small social structure, as a settlement unit, while rural areas are defined as spaces created by villages and their surroundings. The countryside constitutes an important area of living space where a specific culture, customs, traditions, rituals, system of social relations and socialization processes were formed. In sociological research, the characteristic features of rural areas include: specific open landscape, relatively low population density, dominance of the population associated with agriculture and forestry, traditional lifestyle close to nature, extensive land use, few buildings and dispersed settlement, recognition by the majority of inhabitants of the fact of living in the countryside (Turowski 1993).

Similarly, Ewa Bielska (2009, p. 13) believes that a village is a small area of a settlement nature, inhabited by people working on a farm, which is their main or only source of income. It includes the area, buildings and agricultural land used by the inhabitants. In the village personal contacts between inhabitants are closer and more frequent than in the city, as well as a specific type of common and mutual social bonds. The village as a typical form of the environment occupied by the rural community, as opposed to the urban environment, reveals a considerable diversity of its form and, depending on the composition of these features - immanent and indicating its spatial location in the region - provokes sociologists and social pedagogues to make and propose categorizations (classifications and typologies) of rural environments. For example, W. Wincławski (1976) distinguished: a traditional village, a conservative village, an industrialized region village a and suburban village. Stanisław Kawula (2001, p. 472) proposed to distinguish between villages: with dominating individual farms, centrally located villages, post-state farm villages, recreational and tourist villages, suburban villages inhabited by workers, peasant workers, forestry workers and agrocomplexes as concentrations of individual villages. Another suggestion of their categorization, taking into account the criterion of a function that is dominant in a given case, is proposed by Jerzy 
Modrzewski (2016), who distinguished villages with the following dominant functions:

1) the function of agricultural, live stock and horticultural production - these are the environments of a modernized, large-hectare village oriented towards specialized production, with adequate infrastructure and technical facilities and cooperating with institutions generally defined as agribusiness institutions. It is basically a modern village, dominated by medium and large family and farmer-type farms focused on commercial production, on profit, thus revealing their market orientation and experiencing all its consequences, advanced also in its cultural development;

2) the so cial function; these are mainly post-state farm, post-cooperative villages, but also villages that have been peasant for generations, smallholder, autarkic villages traditional in their production function at a level enabling survival but not development, experiencing poverty, large-scale unemployment, resorting to emigration if it is possible, even with modest financial resources. The community of these rural environments has little cultural and social capital, which contributes to their progressive disintegration and sometimes total degradation or disappearance (Wesołowska 2018);

3) the service function; these are typically tourist villages, possessing considerable cultural and human capital: both material and symbolic, raising capital from the provision of tourist services, oriented towards consumption of ethnic and often ecological advantages of these environments and forms of organizing and spending time specific for this type of tourism (the idea of slow life) (Laskowska-Otwinowska 2010). These are also villages and habitats focused on providing agritourism services, villages located near historical sites and health resorts. All of them demonstrate a significant advancement in the process of integration with the European economy and culture;

4) the reside ntial function; these are two types of villages: those located in suburban areas and created (or transformed) into environments serving institutionalized or private residences and "newly-landed gentry" farms. The former function mainly as a hotel for their residents who find employment in the city and sooner or later transform into the city's peripheral districts (in the suburban area); the latter try to restore, with varying results, the system of the farm economy, obviously on the basis of the principles of a market economy with various social security measures for their communities, or save themselves by providing 
residential services (hotel services, organization of parties, conventions, various conferences, hunting, fishing, horse riding schools, etc.) (Modrzewski 2016, p. 143-144);

5) the co m bin ed function; this type of a village seems to be most often represented in Poland, and the direction of its specialization will determine the general image and pace of the integration process of Polish rural communities with the standards of the European Union? ${ }^{7}$.

According to numerous theoretical and research studies, Polish countrysides are subject to constant and fast social and economic changes ${ }^{8}$. The authors of the "Wieś w Polsce 2017: diagnoza i prognoza" report state that "the process of dismantling of state farms and cooperatives, which began in the second half of the 1980s, resulted in the erosion of the institutional and communication infrastructure (nurseries, day-care rooms, libraries, cultural centers, sports fields, sports clubs, transport, etc.). Cutting costs in individual public service systems resulted in the liquidation of not only the "infamous" communist militia stations but also post offices, pharmacies, kindergartens, schools and the remains of cultural institutions. This process had its consequences in the form of atrophy of social fabric and translated into disturbances in the functioning of rural community structures (Sadura et al. 2017). Despite the fact that Polish villages experienced these partly destructive circumstances, to a large extent they retained their typical features such as the superiority of the family, high value of work in direct contact with nature, neighborhood, regionalism combined with traditions and folklore, folk type of religiousness (Matyjas 2012, p. 45) as well as the dominance of direct contacts over indirect ones, their spatial proximity, lower mobility of village inhabitants which is conducive to self-help, locality and homogeneity of rural communities, intergenerational transfer of values and large socio-cultural diversity dependent on tradition, level of economic management, location, specificity of economy, infrastructure conditions, lifestyle of inhabitants and their education (Matyjas 2013, p. 82). In 2018, Jerzy Wilkin (2018, p. 225), in another report on the condition of Polish countryside, reviewing its current state in the light of its 100-year history, after Poland regained its statehood, stated with a great deal

7 It also points to the importance of such processes or phenomena as: deagrarization, proletarianization and gentrification in the dynamics of their transformations - the latter understood as saturating rural communities with urban middle class representatives settling in rural environments (Halamska et al. 2017, Vol. 2, pp. 109-139).

8 A detailed description of the development and transformation of the countrysides and agriculture can be found in the monograph by I. Bukraba-Rylska (2008) indicated above. 
of optimism in his summary that "the countryside has become an attractive place to live in, as evidenced by the positive balance of internal village - city migration since 2000. The educational gap between the city and the village is narrowing, as are many other development gaps (infrastructural, digital, income, etc.)... the countryside has joined not only Poland, but also Europe and is doing there quite well.

\section{Socialization condition and destruction of rural communities}

Already in the report: "Polska wieś 2016" (Wilkin, Nurzyńska 2016, p. 12), its authors signalize the above mentioned dynamics of transformations that Polish countryside and its community undergoes by assimilating and petrifying some features of urban settlements. ${ }^{9}$. It is also pointed out that the most important source of transformation and acceleration of the process of reducing the development gap between the city and the village in Poland is the integration of our country with the European Union and the resulting benefits. The years after 2004, that is, the period of Poland's membership in the European Union, in the opinion of the authors of the quoted report, is the best time for the Polish countryside in its entire history, liberating and dynamizing the phenomena and processes of integration of Polish rural environments into the civilization standards of the western regions of the European Union.

Currently, according to the latest scientific research, rural areas are a very attractive place to live. A significant number of city residents move to rural areas, and the existing residents of rural areas do not intend to move out of them. This means that in recent decades, city residents migrate more often to rural areas than from the latter to urban areas. From the report "Polska wieś 2018" we learn that in the Polish countryside there is still an increase in the number of rural inhabitants and a decrease in the number of city inhabitants (Wilkin, Nurzyńska 2018, p. 12).

Almost $40 \%$ of the country's population lives in rural areas. More young people aged $0-17$ live in villages $-22.1 \%$ compared to $17.5 \%$ in towns and

9 The modern countryside takes over the so-called urban lifestyle. In the opinion of L.J. Beaulieu, the main features of the transformation of the Polish countryside are: the inflow of people representing various habituses, outflow of human capital (talented people), poverty in a primarily feminized form and a tendency to juvenalization and infantilization of poverty, often inability to benefit from high quality health services in the place of residence, requirements for rural schools, professional activity of the rural population outside the local environment, and consequently weakening of social bonds with the inhabitants (Bielska 2009, p. 13-14). 
cities (Szafraniec). The level of education of the rural population is significantly lower than that of the urban population, but the gap is narrowing. Analyses of research and reports do not confirm also the stereotypical opinions about a very low level of social capital and reluctance of rural inhabitants to joint activities. According to the quoted report, farmers' involvement in community service is higher than the country’s average (Wilkin, Nurzyńska 2016, p. 13). The CBOS (Public Opinion Research Center) survey on the condition and development of the Polish countryside, as well as the educational situation of children and youth in rural areas shows that living in rural areas is associated by the majority of respondents with a healthy lifestyle (71\% of responses), but at the same time with everyday difficulties and hard work (61\% of responses). Moreover, the countryside has become more attractive for educated and wealthy people, who decide to live in suburban villages and usually commute to work in the city, but in return get a chance for a better quality of life (their own house with a garden) away from urban inconveniences (Wciórka 2006a).

People living in the countryside were more often than people living in cities regarded as: religious ( $79 \%$ vs. $33 \%$ ), hard-working ( $72 \%$ vs. $45 \%)$, moral ( $62 \%$ vs. $27 \%)$, kind ( $62 \%$ vs. $31 \%)$, honest (50\% vs. $27 \%)$ and generous $(43 \%$ vs. $23 \%)$. As often as people from the city they were considered cultural (46\% vs. $47 \%)$, but much less often they were perceived as resourceful (46\% vs. $64 \%)$ and caring about their appearance (39\% vs. $74 \%$ ), which characteristics are clearly emphasized in the social image of city inhabitants. In the opinion of respondents, rural areas are the mainstay of Polish traditions and old customs $(88 \%)$, in difficult situations they are economically self-sufficient (66\%), they have always been discriminated against by central authorities (65\%), but nowadays it is a greater beneficiary of EU integration than the city (56\%).

The respondents denied opinions that rural areas expect too much aid from the state at the expense of city inhabitants (57\% denied it), but also that they work to support people from the city (60\% denied it), and above all that they are backward ( $87 \%$ denied it). The opinions were divided on whether there was a misunderstanding between village and city inhabitants (46\% confirmed this opinion and 43\% denied it) (Wciórka 2006b). At the end of 2016, there were nearly 6.9 million children aged 0-17 in Poland (CSO 2017). The share of children in the total population of Poland has been decreasing since the 1990s (CSO 2015). In 1990, children under 18 constituted almost $30 \%$ of the total population (CSO 2001), while in 2016 this percentage was less than $18 \%$. Fifty-one percent of children are boys. In cities, the share of children in the population is smaller than in the countryside and amounts to less than 17\%, while in the countryside it is almost $20 \%$ (CSO 2016). However, 
the decrease in the percentage of children in the countryside is faster than in the city. Between 1999 and 2016, the share of children in the countryside population decreased by 8.3 percentage points, while in the city the decrease amounted to 6.6 percentage points (Raport - Dzieci się Liczą, 2017). The indicated demographic changes of the rural population are clearly visible in the state and structure of transformations of rural families. The indicated demographic changes of the rural population are clearly visible in the state and structure of transformations of rural families. Both in the countryside and in all of Poland too few children are born, which does not ensure the generation replacement (Wilkin, Nurzyńska 2018, p. 12).

According to research carried out by e.g. Danuta Markowska, Stanisław Kawula, Bożena Matyjas and Wiesław Ambrozik, a rural family is a specific social group that differs from an urban family. These differences are visible, among others, in the practices of making use the goods of civilization or socialization (education) by rural families and in the image of the lifestyle of its members (Matyjas 2013, p. 145). The present-day rural family is subject to the processes of transformation from traditional families to modern ones, with a change in their structure and educational functions. It more and more often popularizes the model of a small, two-generation family, which is more independent of the family of origin and neighborhood than it was in the past, and which enters into contacts and supra-local ties (Ambrozik 1997, p. 20).

In the rural family we can observe the departure of its members from the patriarchal system of social relations and the emergence of a democratic system with the growing role of women, mothers and the importance of emotional and expressive functions, with a clearly noticeable empowerment of children in the family (Ambrozik 1997, p. 20). Unfortunately, the rural family suffers from poverty and scarcity more than the urban family. The village inhabitants account for more than $60 \%$ of the people living in extreme poverty in our country. The highest poverty rate is observed in the Warmińsko-Mazurskie and Świętokrzyskie Voivodeships. Despite the gradual blurring of the division into Poland A and Poland B in terms of the level of income, educational indicators and basic infrastructure, the social and economic condition of rural families does not encourage optimism (Golinowska 2018).

Polish farmers (although not all of them to an appropriate extent) and their families benefit from a highly developed support system providing reliefs and co-financing from the budget with regard to both central and local taxes, as well as social and property insurance, which often constitutes a "protective umbrella" in order to maintain the status of a farmer (Wilkin, Nurzyńska 2016, pp. 17-18). Another problem for rural families is the permanent threat 
of unemployment. Over $1 / 3$ of the total number of the unemployed, both in villages and cities, are people who have been looking for a job for a long time, among whom the share of those who have been unemployed for over 24 months has increased in rural areas from $14.2 \%$ to $16.9 \%$. In 2016, the average income of households in cities was by as much as $35 \%$ higher than in the countryside. Villages and small towns are the source of the largest group of households with regular incomes that do not allow them to satisfy the basic needs of family members (Golinowska 2018, p. 142).

Other problems occurring in rural families include: social marginalization, low cultural capital, culture of poverty, difficult housing and social conditions, low education of parents, low pedagogical awareness of parents, low cultural competence of parents and children, excessive drinking and alcoholism among adult members of rural families, poor culture of spending free time, crime and social maladjustment of rural youth (Błażejewski 1994; Noszczyk-Bernasiewicz 2009), pedagogical negligence towards children and poor health of all family members.

In his superficial description of the cultural condition of Polish communities of villages and small towns in Poland Tomasz Szlendak (2011, p. 53-62) writes: "Polish villages and towns are characterized by a specific cultural landscape, which consists of the order and aesthetics of public space and the specificity of private space, social construction of time and communication, social characteristics of people living here, all similarly shaped in the whole country. In other words, culture happens here in a specific, possible to reconstruct and generalize "spatial-temporal-social environment" [...]. There's no culture in the countryside. In the countryside, according to its inhabitants, there is nature $[\ldots]$. Tradition and religious rituals are the foundation of life and cultural activity". Andrzej Kaleta (2004, p. 67) points out that in rural households the necessity to give up the education of children is accepted only by $3 \%$ of the village inhabitants. According to the author, the requirements of living and working in the global and information society shift the educational needs of the rural population from the hitherto dominant vocational education to general education.

Krystyna Szafraniec (2001, p. 126-127), on the other hand, points out that "a broad and comprehensive educational project connected with a longterm local development programme, taking into account in the first place the needs and aspirations of children and youth, is an opportunity for the development of rural areas". According to the author, rural youth want to study in a degree never seen before; as much as $48 \%$ of the surveyed group of respondents would like to go to university. However, due to material problems 
of parents of rural youth (the scale of poverty, depending on the region, ranges from 60 to $80 \%$ ), its share among university students is decreasing (up to $10 \%$ in full-time studies and $8.6 \%$ in evening and weekend studies). The young people in rural areas are aware of their parents' material limitations and for this reason they often get lower education than the one they aspire to. The most popular among rural youth are small businesses and jobs related to economics. At the top, apart from the above-mentioned professions, taking into account the possibility of fulfilling the aspirations, there are qualified workers and specialists whose skills meet the requirements of the new economy (Gorlach et al. 2003, p. 54-57).

These data illustrate the pluralism of interests and career plans, the correct reactions of rural youth to the requirements of the market economy, and a large percentage of people pointing to workers' professions indicates sharing the awareness of the existence of limitations in planning their own professional future, which is also indicated by the research conducted by T. Wilk ${ }^{10}$. Rural and small-town youth want to invest in education, although their aspirations often remain in the sphere of unsatisfied desires (economic situation of the country, region, family). E. Tarkowska (2005, p. 30 et seq.), when dealing with the problems of young people from disfavored environments, in relation to the education system pointed to such barriers as: unavailability of pre-school education, underfunding of rural schools, difficult learning conditions, necessity of daily commuting (which makes it impossible to participate in extracurricular activities), school segregation policy (e.g. separate classes for children from wealthy families and poor families, existence of the so-called "bundle classes") (Leszczyńska 2004). It is also the process of selection for better and worse segments of the school system ("apartheid in primary school", "high schools for the worse ones", "higher school of this and that") ${ }^{11}$. The author calls for higher scholarships for rural youth who want to study, the need for continuity of financial support, expanding the activities of sports clubs, scouts and other youth organizations, external financial support

10 An empirical research was conducted in 1998 among 480 students of final grades of general high schools in selected cities of Kielce voivodship and among 480 final grade students in general high schools in Katowice (Wilk 2003).

${ }_{11}$ The research on school selections of children and youth in Poland has a long and glorious tradition dating back to its genesis of the interwar period, and their revival and dynamic development after the war resulted in a remarkable contribution illustrating the actual "educational paths" of successive generations of youth and a generally complete index of factors determining their form, dynamics and educational barriers that cause concern among the pedagogues with their stratifying deficiencies (Smolińska-Theiss 2014). 
for schools - "local sponsoring", stimulating, developing and supporting young people's aspirations by teachers, and many others (Tarkowska, Korzeniowska 2002).

The report "Młodzież na wsi", whose authors characterized the deficiencies of rural youth on the basis of the conducted research, states that most often these are: deficiencies of the available offer (e.g. of equal access, access to culture, activities on the peripheries, high quality studies), deficiencies of social relations (e.g. of diversified contacts, partners, allies, associates), deficiencies of competences and knowledge (e.g. technological competences, information about programmes), deficiencies of space (places, activities outside institutions, utilization of local resources), deficiencies of the horizon of choice (e.g. time, ideas, experiences), deficiencies in relations between young people and institutions (e.g. understanding needs, trust, participation), deficiencies in cooperation (between institutions and parents, between institutions and between municipalities) (Strzemińska, Wiśnicka 2011).

In regards the educational situation in the countryside, Tadeusz Pilch (2001, p. 134) rightly states that it is still alarming. The author points to the fact that libraries, all cultural institutions or adult education initiatives have been liquidated in the countryside, there are no commercialized educational offers in the countryside, kindergartens and schools are being constantly liquidated (Marzec-Holka 2015) and the costs of schools and boarding fees increased dramatically. In the author's opinion, scholarship aid for the poorest children in Poland is minimal (Pilch 2001, p. 135). Similarly, Katarzyna Palka (2014, p. 362) states that living in the countryside alone brings with it many barriers which make it difficult not only to obtain higher education, but also to access the broadly understood knowledge.

In the author's opinion, the inequalities in educational opportunities concern three areas: inequality of access (especially to kindergartens, additional activities organized in schools and other educational and cultural institutions, to high schools and universities and to schools located close to home, which is often a consequence of liquidation of schools in rural areas), inequality of conditions - differences in the family situation of children and youth coming from cities and villages (they concern the education of parents, their financial situation, aspirations concerning the education of children and pedagogical awareness), differences in resources and quality of schools in rural and urban areas, in resources of rural and urban local environment and thirdly, inequality of results - learning outcomes - between students from cities and rural areas (differences in the results achieved at the level of competence tests and in the proportions of students) (Palka 2014, p. 362 et seq.). 
Jan Papież (2006, p. 481), after conducting numerous studies on the changes in social and educational conditions in villages, indicates that "the cultural backwardness of rural areas continues, although political, social and economic conditions are changing [...]. In this situation, particular disadvantages are suffered by students with medium and high mental abilities who, despite their abilities, achieve a low level of cognitive competence (functional illiteracy), largely determined by their own living environment.

Many reports show that rural youth undertaking higher education are more likely to choose part-time studies and study at private universities. They also rarely study at prestigious universities and gain professions enjoying high social trust or enabling professional advancement (Nadobnik 2011, p. 7 et seq.). The reasons for the above situation may include: limited access to tutoring, paid language courses, artistic, IT or sports activities - this applies in particular to children from peasant families (2\% of farmers' children expand their knowledge of foreign languages, while in the city it is $28 \%$ of children) (Nadobnik 2011, p. 8).

The research of Jan Papież (2006), Tadeusz Pilch (1999, 2000), Zbigniew Kwieciński (2002), Monika Kwiecińska-Zdrenka (2004), Iwona Chrzanowska (2009), Justyna Truskolaska (2010), Danuta Waloszek (2001), Bożena Matyjas (2012a) and many others, who analyze the issues of socialization of children and youth in villages, sufficiently justify the statement that the education system in Polish rural areas requires immediate changes in favor of the "second chance" (Waloszek 2005, p. 83). Bożena Matyjas (2012a, p. 169) is correct in writing that contemporary Polish rural areas are clearly differentiated in terms of economy and culture, and the situation of children and youth is not everywhere and not always negative. According to the author, there are villages, especially those located closer to cities, where the living conditions of the inhabitants, especially in terms of access to cultural and educational infrastructure and employment opportunities in the city appear to be very good. Undoubtedly, the situation of rural youth is changing also through the access to mass media, especially through the development of access to broadband Internet in rural areas, which becomes a kind of "window to the world" and offers many opportunities for e-learning education and personal development.

\section{Final thoughts}

Rural environments, despite the progressive destruction of the traditional rural community, still constitute a specific reservoir of development factors, 
assuming the characteristics of an ecologically attractive place to live in, where national tourism and active forms of spending free time by all types of social people can be developed. It is an area of economic locations of new business ventures, a renewable source of income for the inhabitants of villages, a place of realization of modern services for agriculture and a source of creating an attractive environment for farmers.

In the perspective of the development of rural areas B. Klepacki (2001, p. 89) optimistically predicts that in the near future the cultural, intellectual, educational and prestige gaps between the inhabitants of cities and villages should disappear, rural areas will become an opportunity for the deglomeration of big cities and metropolises as a result of the creation of "rural towns", small agri-food processing plants will develop, and rural areas will be appreciated for their natural and landscape values. The rural areas will become a refuge for many people who do not want to live in the "global village" - exposed to uniformity, constant influence of international corporations and globalization (Klepacki 2001, p. 90). In the future, villages will be less and less agricultural in character, rural life will be disintegrated and fragmented, their detraditionalisation, caused by an inflow of population from cities, will be more and more noticeable, and rural areas will become multiracial and multinational.

According to Bogdan Klepacki (2001, p. 91 et seq.), education of people at all stages of life becomes the most important element in the strategies for changing Polish rural areas. The education should be continuous and should develop in the direction of learning unique professions, including those traditionally connected with rural areas. The rural environment is a "clean" area where scientific, research and design institutions, hospitals, health resorts and universities could be located. In rural environments it is necessary to create and disseminate the models of success, rather than of failure, to motivate local community members to actively participate in the creation of community.

The most important issue concerning the development of Polish rural areas and the future of next generations of Poles is education. The report "Wieś w Polsce 2017 - diagnoza i prognoza" shows that $71 \%$ of respondents - local leaders - see the quality of education as a factor determining the future of Polish rural areas (Sadura et al. 2017). The indication of this form of specific pedagogization of rural communities as a remedy for their cultural and economic "handicap", for their cultural and economic advancement, undoubtedly has its historical and contemporary references. It should be seen and relativized to the context of numerous, non-educational conditions of advancement and the civilizational blockade of rural communities, rooted 
both in themselves as well as in the national and supra-national realities of their existence and functioning, in order to avoid succumbing to the illusion in assigning an overly salutary inclusive function to education (Pluskota-Lewandowska 2008).

\section{References}

Ambrozik W., 1997, Dewiacje wychowawcze w środowisku wiejskim, Poznań.

Bańka A., 2018, Psychologia środowiskowa. Jakość życia i innowacji społecznych, Poznań-Katowice.

Bell P.A., Greene Th.C., Baum A., 2004, Psychologia środowiskowa, Gdańsk.

Bernard J., 1962, American Community Behavior, Vol. 4, New York.

Bielska E., 2001, Społeczeństwo w procesie przemian a ciagłość pedagogiki społecznej, [in:] Pedagogika społeczna. Tradycja - teraźniejszość - nowe wyzwania, eds. E. Trempała, M. Cichosz, Olecko.

Bielska E., 2009, Patologia środowisk wiejskich - wybrane aspekty $i$ kontrowersje, "Auxilium Sociale Novum", no. 1-2.

Błażejewski Z., 1994, Przestępczość nieletnich w środowisku wiejskim, Szczecin.

Borowicz R., 2000, Nierówności społeczne w dostępie do wykształcenia. Casus Suwalszczyzny, Olecko.

Bukraba-Rylska I., 2013, Socjologia wsi polskiej, Warszawa.

Bukraba-Rylska I., 2019, Kultura wsi - kontekst lokalny, narodowy, globalny, [in:] Ciągłość i zmiana. Sto lat polskiej wsi, t. 1, eds. M. Halamska i in., Warszawa.

Buttel F.H., 2001, Rural sociology, [in:] International Encyclopedia of the Social and Behavioral Sciences, eds. N. Smelser, P.B. Baltes, Amsterdam-New York.

Chałasiński J. (ed.), 1938, Młode pokolenie chłopów, Warszawa.

Chałasiński J. (ed.), 1969, Młode pokolenie wsi Polski Ludowej, Warszawa.

Chrzanowska I., 2009, Zaniedbane obszary edukacji - pomiędzy pedagogika a pedagogika specjalną. Wybrane zagadnienia, Kraków.

Czyżewski M., Marynowicz-Hetka E., Woroniecka G. (eds.), 2013, Pedagogizacja życia społecznego, "Societas/Communitas", no. 2(16).

Damrosz J. (red.), 1979, Tradycja i nowoczesność w kulturze wsi, Warszawa.

Domalewski J., 2001, Szkoła wiejska wobec zadania rekompozycji struktury społecznej, "Przegląd Socjologiczny", no. 1.

Domalewski J., 2019, Szkoła wiejska jako moderator zmian systemowych, [in:] Ciągłość i zmiana. Sto lat rozwoju polskiej wsi, Vol. 1, eds. M. Halamska i in., Warszawa.

Dudkiewicz W., 1990, Dziecko wiejskie, Kielce.

Frąckowiak T., 2005, Lokalność i wspólnota, [in:] Społeczne procesy modernizacyjne $w$ środowisku lokalnym średniego miasta (doświadczenia i propozycje), eds. T. Frąckowiak, P. Mosiek, A. Radziewicz-Winnicki, Rawicz-Leszno.

Golinowska S., 2018, O polskiej biedzie w latach 1990-2015. Definicje, miary i wyniki, Warszawa. Gołębiowski B., 1977, Dynamika aspiracji, Warszawa.

Gorlach K., 2004, Socjologia obszarów wiejskich. Problemy i perspektywy, Warszawa.

Gorlach K., Drąg Z., Seręga Z., 2003, Młode pokolenie III Rzeczypospolitej. Aspiracje życiowe w przeddzień integracji $z$ Uniq Europejską, Warszawa.

Grabski W., 1987, Kultura i oświata na wsi, [in:] W. Grabski, Wybór pism, Warszawa. 
Halamska M., Hoffmann R., Stanny M., 2017, Studia nad strukturq społeczna wiejskiej Polski, Vol. 2, Warszawa.

Halamska M., Stanny M., Wilkin J. (eds.), 2019, Ciagłość i zmiana. Sto lat rozwoju polskiej wsi, Vol. 1 i 2, Warszawa.

Hawley A.H., 1950, Human Ecology: A Theory of Community Structure, New York.

Hejnicka-Bezwińska T., 1998, Pedagogizm (kontynuacja-przezwyciężenie), [in:] Tradycja i wyzwania: księga pamiątkowa na 75-lecie założenia Studium Pedagogicznego Uniwersytetu Jagiellońskiego 1927-1996, ed. K. Pacławska, Kraków.

Hryniewicz T., 1991, Religia, osobowość a perspektywy kapitalizmu na wsi polskiej, "Studia Socjologiczne", no. 1-2.

Janowitz M. (ed.), 1961, Community Political Systems, Glencoe.

Kaleta A., 1991-2013, Socjologia i socjologowie, Toruń.

Kaleta A., 1996-2001, Rewitalizacja obszarów rustykalnych Europy, Ossolineum.

Kaleta A., 2004, Potrzeby edukacyjne mieszkańców wsi, [in:] Stare i nowe struktury społeczne $w$ Polsce. Terytorialne struktury społeczne, ed. D. Niczyporuk, Lublin.

Kamiński A., 1974, Funkcje pedagogiki społecznej, Warszawa.

Kawula S., 1973, Rodzina wiejska a wychowanie. Szczegółowe studium porównawcze, Toruń.

Kawula S., 2001, Dylematy pedagogiki społecznej na koniec XX wieku, [in:] Pedagogika społeczna. Tradycja - teraźniejszość - nowe wyzwania, eds. E. Trempała, M. Cichosz, Olecko.

Kawula S., 2002, Pomocniczość i wsparcie, Olsztyn.

Kielar M., Radochoński M. (eds.), 1989, Rozwój i wychowanie dziecka wiejskiego, Rzeszów.

Klepacki B., 2001, Warunki i szanse rozwoju polskiej wsi, [in:] Przyszłość wsi polskiej. Wizje, strategie, koncepcje, eds. L. Kolarska-Bobińska, A. Rosner, J. Wilkin, Warszawa.

Kowalski S., 1969, Szkoła w środowisku, Warszawa.

Kowalski S., 1974, Socjologia wychowania $w$ zarysie, Warszawa.

Kowalski S., 1996, Metodologiczne zagadnienia integralnego funkcjonowania społeczeństwa, "Studia Pedagogiczne", Vol. 32.

Kozakiewicz M., 1989, Edukacja na wsi. Stan i kierunki przebudowy, Warszawa.

Kurczewska J., Kempny M., Bojar H., 1998, Społeczności lokalne jako wspólnoty tradycji - w poszukiwaniu korzeni demokracji, "Kultura i Społeczeństwo", no. 3.

Kwaśniewicz W., 1976, Wieś jako środowisko wychowawcze, Kraków.

Kwiecińska-Zdrenka M., 2004, Aktywni czy bezradni wobec własnej przyszłości, Toruń.

Kwieciński Z., 1972, Funkcjonowanie szkoły w środowisku wiejskim, Warszawa.

Kwieciński Z., 2002, Bezbronni. Odpad szkolny na wsi, Toruń.

Kwieciński Z., 2011, Pedagogizm - wariacje wokót rozumienia kategorii, "Przegląd Pedagogiczny", no. 1.

Lambeir B., Ramaekers S., 2008, Humanizing education and the educationalization of Health, "Educational Theory", no. 4.

Laskowska-Otwinowska J., 2010, Podróże do pracy jako element nowego stylu życia. Postulaty ruchu społecznego slow down, "Kultura i Społeczeństwo", no. 1.

Leszczyńska A., 2004, Segregacja klasowa w polskich szkołach, "Gazeta Wyborcza”, 5 lipca.

Łoś M., 1972, Aspiracje a środowisko, Warszawa.

Markowska D., 1976, Rodzina w społeczności wiejskiej - ciagłość i zmiana, Warszawa.

Marzec-Holka K., 2015, Kapitał społeczny a wspólnoty wiejskie w obronie "małych szkół”, Bydgoszcz.

Matyjas B., 2012a, Dzieciństwo na wsi. Warunki życia i edukacji, Kraków.

Matyjas B., 2012b, Szanse edukacyjne dziecka wiejskiego: stan, uwarunkowania i perspektywy, "Chowanna", no. 1. 
Matyjas B., 2013a, Dziecko na wsi. Perspektywa życia i edukacji, [in:] Zagrożenia człowieka i idei sprawiedliwości społecznej, eds. T. Pilch, T. Sosnowski, Warszawa.

Matyjas B., 2013b, Srodowisko wiejskie jako przestrzeń życia dzieci i młodzieży. Szanse i bariery, [in:] Pedagogika społeczna wobec zmian przestrzeni życia społecznego, eds. M. Sobecki, W. Danilewicz, T. Sosnowski, Warszawa.

Mendel M., Theiss W. (eds.), 2019, Pamięć i miejsce. Perspektywa społeczno-edukacyjna, Gdańsk. Milas E., 1980, Rodzina wiejska, Warszawa.

Modrzewski J., 2007, Socjalizacja i uczestnictwo społeczne, Poznań.

Modrzewski J., 2016, Polska wieś wobec kulturowo-edukacyjnych wyzwań integracji z Unia Europejską, [in:] Socjopedagogika. Studia - szkice - refleksje - wspomnienia, Poznań.

Nadobnik B., 2011, Nowoczesna wieś: po pierwsze edukacja, Warszawa.

Nowak W., 1988, Społeczne uwarunkowania przemian funkcji socjalizacyjno-wychowawczej rodzin chłopskich, "Kultura i Społeczeństwo", no. 1.

Nikitorowicz J., 1992, Socjalizacja $i$ wychowanie $w$ zróżnicowanych wyznaniowo $i$ etnicznie rodzinach białostocczyzny, Białystok.

Noszczyk-Bernasiewicz M., 2009, Przejawy patologii społecznych na przykładzie młodzieży wiejskiej, "Auxilium Sociale Novum", no. 1-2.

Ossowski S., 1984, O ojczyźnie i narodzie, Warszawa.

Palka K., 2014, Edukacja na wsi - mechanizmy wykluczenia edukacyjnego, [in:] Pedagogika społeczna wobec zagrożeń człowieka i idei sprawiedliwości społecznej, eds. W. Danilewicz, W. Theiss, Warszawa.

Papież J., 2006, Przemiany warunków socjalizacyjno-edukacyjnych na wsi. Badania panelowe, Kraków.

Papież J., 2007, Srodowisko wiejskie, [in:] Encyklopedia Pedagogiczna XXI wieku, Vol. 6, ed. T. Pilch, Warszawa.

Park R.E., 1936, Human ecology, "American Journal of Sociology”, Vol. XLII.

Pilch T., 1999, Spory o szkołę. Pomiędzy tradycja a wyzwaniem wspótczesności, Warszawa.

Pilch T., 2001, Edukacja a społeczne procesy marginalizacji, [in:] Pedagogika społeczna. Tradycja - teraźniejszość - nowe wyzwania, eds. E. Trempała, M. Cichosz, Olecko.

Pilch T., 2002, Środowisko lokalne, [in:] Elementarne pojęcia pedagogiki społecznej i pracy socjal$n e j$, eds. T. Pilch, D. Lalak, Warszawa.

Pilch T., 2016, Uczniowie na drogach Warmii i Mazur. Narodziny nierówności, Olsztyn.

Pilch T. (ed.), 2000, O potrzebie dialogu i kultur, Warszawa.

Pilch T. (ed.), 2003-2010, Encyklopedia pedagogiczna XXI wieku, Warszawa.

Pluskota-Lewandowska A., 2008, Inkluzja czy iluzja? O nauczaniu całożciowym jako szansie na integrację zmarginalizowanych, [in:] Socjologia jako społeczna terapia, ed. A. Wachowiak, Zielona Góra.

Przecławska A. (ed.), Theiss W., 1996, Pedagogika społeczna: nowe zadania i szanse, [in:] Pedagogika społeczna. Kręgi poszukiwań, Warszawa.

Radochoński M., Horbowski A. (eds.), 1996, Problemy edukacji dziecka wiejskiego, Rzeszów.

Radziewicz-Winnicki A., 2003, Środowisko lokalne jako przestrzeń edukacji obywatelskiej. [in:] Przemiana, myśl, poznanie. Księga jubileuszowa poświęcona profesorowi Wojciechowi Pasterniakowi, ed. T. Frąckowiak, Poznań.

Raport, 2017, Dzieci się Liczą, Warszawa.

Sadura P., Murawska K., Włodarczyk Z., 2017, Wieś w Polsce 2017: diagnoza i prognoza. Raport $z$ badania - petna wersja, Warszawa.

Sipińska D., Modrzewski J., Matysiak-Błaszczyk A. (eds.), 2010, Socjalizacja inkluzyjna, Vol. 1,. Leszno. 
Smolińska-Theiss B., 2014, Z tradycji badań nad nierównościami edukacyjnymi - od społecznych przyczyn powodzeń i niepowodzeń szkolnych do współczesnych badań nad zróżnicowaniami w oświacie, [in:] Edukacja i nierówność. Trajektorie sukcesu i marginalizacji, eds. A. Gromkowska-Melosik, M.J. Szymański, Poznań.

Sroczyński W., 2006, Pedagogika środowiskowa. Kategoria środowiska $w$ teorii polskiej pedagogiki społecznej, Warszawa.

Sroczyński W., 2017, Szkice do pedagogiki środowiskowej, Siedlce.

Stanny M., 2014, Wieś, obszar wiejski, ludność wiejska - o problemach $z$ ich definiowaniem. Wielowymiarowe spojrzenie, "Wieś i Rolnictwo", no. 1(162).

Starosta P., 2002, Społeczność lokalna, [in:] Encyklopedia socjologii, t. 4, eds. K.W. Frieske i in., Warszawa.

Strzemińska A., Wiśnicka M., 2011, Młodzież na wsi, Warszawa.

Styka J., 1993, Chłopskie widzenie świata i siebie, Włocławek.

Styka J., 1995, Światopogląd i religia a tożsamość społeczno-kulturowa mieszkańców wsi, [in:] Socjologia wsi i rolnictwa, wyd. 2, ed. J. Turowski, Lublin.

Styka J., 1999, Chłopi i wieś, polska w perspektywie socjologicznej i historycznej, Lublin.

Szafraniec K., 2001, Ludzie - podstawowy kapitał polskiej wsi, [in:] Przyszłość wsi polskiej. Wizje, strategie, koncepcje, eds. L. Kolarska-Bobińska, A. Rosner, J. Wilkin, Warszawa.

Szafraniec K. (red.), 2006, Kapitał ludzki i zasoby społeczne wsi. Ludzie - społeczność lokalna edukacja, Warszawa.

Szlendak T., 2011, Nic? Aktywność kulturalna i czas wolny na wsi $i$ w malych miastach, [in:] Stan $i$ zróżnicowanie kultury wsi i małych miast $w$ Polsce, eds. I. Bukraba-Rylska, W.J. Burszta,Warszawa.

Tarkowska E., 2005, System edukacji a problemy młodzieży ze środowisk defaworyzowanych, [in:] Edukacja przeciw wykluczeniu. Teoria i praktyka, red. Z. Sirojć, Warszawa.

Tarkowska E., Korzeniewska K., 2002, Młodzież z byłych PGR-ów, Warszawa.

Theiss M. (ed.), 2018, Lokalne obywatelstwo społeczne $w$ polityce społecznej, Warszawa.

Trohler D., 2013, Between universally claimed theory and common understanding. Theoretical knowledge in education, [in:] Making a Difference in Theory, eds. G. Besta, J. Allan, R. Edwards, London-New York.

Truskolaska J., 2010, Opieka, wychowanie i partnerstwo $w$ rodzinach wiejskich i miejskich województwa lubelskiego na początku XXI wieku, Lublin.

Turowski J., 1993, Socjologia wsi i rolnictwa, Lublin.

Turowski J., 1994, Socjologia. Wielkie struktury społeczne, Lublin.

Waloszek D., 2001, Szanse edukacyjne młodego pokolenia ze środowisk wiejskich; dokument czasu przemian, Zielona Góra.

Waloszek D., 2005, Edukacja dzieci na wsi. Studium możliwości, "Pedagogika Społeczna. Profilaktyka - Pomoc - Resocjalizacja”, no. 1.

Wciórka B., 2006a, Polacy o życiu na wsi i w mieście - opinie z lat 1998 i 2006, Komunikat no. 593 (data wydania: 12.09.2006).

Wciórka B., 2006b, Społeczny wizerunek mieszkańców wsi i miast - opinie z lat 1993, 1998 i 2006. Komunikat no. 3604 (data wydania 5.10.2006).

Wesołowska M., 2018, Wsie zanikające $w$ Polsce. Stan, zmiany, modele rozwoju, Lublin.

Wilk T., 2003, Edukacja, wartości i style życia reprezentowane przez wspótczesna młodzież w Polsce $w$ odmiennych regionach gospodarczych, Kraków.

Wilkin J., Nurzyńska I., 2016, Polska wieś 2016. Raport o stanie wsi, Warszawa.

Wilkin J., 2018, Ewolucja wsi i rolnictwa w Polsce w okresie stulecia 1918-2018, [in:] Polska wieś 2018. Raport o stanie wsi, eds. J. Wilkin, I. Nurzyńska, Warszawa. 
Wincławski W., 1973, Przemiany środowiska wychowawczego wsi w rejonie uprzemysławianym. Studium porównawcze 20 wsi gromady Bielsk $w$ powiecie płockim, Warszawa.

Wincławski W., 1976, Typowe środowiska wychowawcze współczesnej Polski, Warszawa.

Winiarski M., 2000, Rodzina, szkoła, środowisko lokalne. Problemy edukacji środowiskowej, IBE, Warszawa.

Winiarski M., 2003, Edukacja środowiskowa - istota, wymiary, aktualne problemy, [in:] Pedagogika społeczna. Dokonania - aktualność - perspektywy, ed. S. Kawula, Toruń.

Winiarski M., 2017, W kręgu pedagogiki społecznej: studia, szkice, refleksje, Łódź.

Zych R. (ed.), 1998, Socjologia wsi. Wybór tekstów i literatury socjologicznej, Rzeszów.

\section{Internet sources}

Szafraniec K., Młodzież na obszarach wiejskich w Polsce. Instytut Rozwoju Wsi i Rolnictwa PAN, prezentacja multimedialna. http://ksow.pl/fileadmin/user_upload/ksow.pl/pliki/Baltic SeaStrategy/2010.10-26-27-konf/26paz/03_26_10_Młodzież_wiejska_PL.pdf (access date: 10.3.2019). 